\title{
Influence of Storage Duration on Stability and Sensorial Quality of Dried Beef Product (Kilishi)
}

\section{Iheagwara $\mathrm{MC}^{1^{*}}$ and Okonkwo $\mathrm{TM}^{2}$}

${ }^{1}$ Department of Food Science and Technology, Federal University of Technology, Owerri, Imo State, Nigeria

${ }^{2}$ Department of Food Science and Technology, University of Nigeria, Nsukka, Enugu State, Nigeria

\begin{abstract}
This study was designed to investigate the influence of storage duration on the stability and sensorial quality of kilishi samples. The conventional traditional kilishi (TK) and sausage-type (SK) at varying percentage of ingredients were processed. Chemical and sensorial analyses were performed to investigate quality changes and to determine the shelf stability of the kilishi samples stored at $28 \pm 2^{\circ} \mathrm{C}$ for 150 days. The proximate, peroxide value (PV), free fatty acid (FFA) and thiobarbituric acid (TBA) were found statistically significant $(\mathrm{P} \leq 0.05)$ in the kilishi samples throughout storage. The lowest PV $(8.24 \mathrm{mEq} / \mathrm{kg}), \mathrm{FFA}(3.12 \%$ oleic acid) and TBA $(0.26 \mathrm{mgMDA} / \mathrm{kg})$ were recorded in SK7 $(115 \%$ ingredients), while the highest PV $(35.11 \mathrm{mEq} / \mathrm{kg})$, FFA $(11.18 \%$ oleic acid) and TBA (1.57 mgMDA/kg) occurred in SK2 (85\% ingredients). Highest protein (55.84 $\pm 0.05 \%)$, fat (19.20 $\pm 0.09 \%)$ and ash $(5.58 \pm 0.08 \%)$ were obtained from SK7, SK2 and SK7 respectively and the organoleptic results showed that SK2 had the best acceptance and was significantly different $(P \leq 0.05)$ compared to the other kilishi samples.
\end{abstract}

Keywords: Storage; Stability; Meat; Quality; Kilishi

\section{Introduction}

Meat is an animal tissue used as food [1]. It is composed of tissue or muscle fibre cells, fat and connective tissue, it can also be composed of pieces of bone [2,3]. Meat plays an important role in nutrition as a contributor of high quality protein. However, meat is a highly perishable food item due to abundance of a number of nutrients that favor the establishment, growth and multiplication of microorganisms [4]. In the tropics, meat spoils quickly a few hours after the outset of rigor-mortis and post-mortem handling, hence meat needs to be preserved. A major meat preservation technique whose use dates back to records from $12^{\text {th }}$ Century is sun drying [5,6]. Today, a variety of sun-dried meat products exist. They include amongst others: the Pemmican that is prepared by exposing strips of lean meat to the sun, the Charqui, which is native to South American and Biltong found in South Africa [7]. In Nigeria, the dried meat product kilishi constitute one of daily delicacies and is equivalent to Pemmican and Charqui. Kilishi is a traditional sun dried Nigerian and Sahara African meat product processed using lean beef in combination with plant ingredients. It contains about $46 \%$ meat and $54 \%$ non-meat ingredients. A finished product contains about $50 \%$ protein, $75 \%$ moisture, $18 \%$ lipid and $9.8 \%$ fibre/ ash respectively $[8,9]$. It is a rich nourishing snack and a source of supplementary animal protein formulated using hurdle technology. Salting, dehydration or sun drying and packaging are hurdles applied in sequence to inhibit deteriorating microorganism [10]. Traditionally, Kilishi is prepared from boneless lean meat that is sliced in sheet of $2 \mathrm{~mm}$ thickness and partially dried in the sun followed by immersion in a slurry of ingredients before a second period of sun drying and brief roasting to stabilize the protein $[11,12]$. As a ready-to-eat convenience meat product, Kilishi possess an excellent shelf-life. According to Igene et al. [13] and Isah and Okubanjo [14], Kilishi has a shelf life of 12 months at room temperature. The ability of the product to keep for several months at room temperature is fast making the product a household name. This study therefore is aimed at evaluating the influence of storage duration on the stability and sensorial quality of Kilishi.

\section{Materials and Methods}

\section{Raw materials procurement}

The fresh beef muscles (Longissimus dorsi) used for the study was purchased from butchers at central Abattoir in Owerri, Nigeria. Spices such as ginger (Zingiber officinale), alligator pepper, (Afromomum meleguata), black pepper (Piper guineense), red pepper (Capsicum frutescens), sweet pepper (Capsicum annum), African nutmeg (Monodora myristica) as well as ingredients such as groundnut paste (Arachis hypogea), garlic (Allium sativum), onion (Allium cepa), sugar, salt and magi seasoning were bought from a grocery shop in Owerri, Nigeria.

\section{Sample preparation and processing}

Meat preparation: The semitendinosus muscle of beef $(9 \mathrm{~kg})$ used for the study was trimmed of all visible fat, bone and connective tissue and then weighed. About $1 \mathrm{~kg}$ of the resultant lean beef $(8.2 \mathrm{~kg})$ was sliced into thin sheets of $0.17 \mathrm{~cm}$ to $0.20 \mathrm{~cm}$ thick and $60 \mathrm{~cm}$ to 80 $\mathrm{cm}$ long along the fibre direction and dried for the traditional kilishi (TK). While $1 \mathrm{~kg}$ each of the remaining resultant lean beef will be comminuted with different percentage of the infusing ingredients to form the sausage-type kilishi (SK).

Preparation of infusing ingredients: Infusion slurry was prepared following the procedures of Igene [8] using the ingredients as shown in Table 1. The fresh groundnut paste was prepared from grains of dry uncooked groundnut after extraction of oil by pressing. The various ingredients were ground and mixed thoroughly with water to form slurry.

Preparation of kilishi: The dried thin sheets of meat were soaked in the infusion slurry for about $30 \mathrm{~min}$, after which it was taken out

*Corresponding author: Iheagwara MC, Department of Food Science and Technology, Federal University of Technology, Owerri, P.M.B 1526 Owerri, Imo State, Nigeria, Tel: +2348032922630; E-mail: marcquin.iheagwara@futo.edu.ng

Received February 17, 2016; Accepted March 09, 2016; Published March 18 2016

Citation: Iheagwara MC, Okonkwo TM (2016) Influence of Storage Duration on Stability and Sensorial Quality of Dried Beef Product (Kilishi). J Food Process Technol 7: 574. doi:10.4172/2157-7110.1000574

Copyright: ( 2016 Iheagwara MC, et al. This is an open-access article distributed under the terms of the Creative Commons Attribution License, which permits unrestricted use, distribution, and reproduction in any medium, provided the original author and source are credited. 


\begin{tabular}{|c|c|c|c|c|c|c|c|c|}
\hline Ingredients & TK & SK1 & SK2 & SK3 & SK4 & SK5 & SK6 & SK7 \\
\hline Ginger (Zingiber officinale) & 3.30 & 3.30 & 2.81 & 2.97 & 3.14 & 3.47 & 3.63 & 3.80 \\
\hline Alligator pepper (Afromomum meleguata) & 1.20 & 1.20 & 1.02 & 1.08 & 1.14 & 1.26 & 1.32 & 1.38 \\
\hline Black pepper (Piper guineense) & 3.00 & 3.00 & 2.55 & 2.70 & 2.85 & 3.15 & 3.30 & 3.45 \\
\hline Red pepper (Capsicum frutescens) & 2.00 & 2.00 & 1.70 & 1.80 & 1.90 & 2.10 & 2.20 & 2.30 \\
\hline Sweet pepper (Capsicum annum) & 2.00 & 2.00 & 1.70 & 1.80 & 1.90 & 2.10 & 2.20 & 2.30 \\
\hline Onion (Allium cepa) & 12.00 & 12.00 & 10.20 & 10.80 & 11.40 & 12.60 & 13.20 & 13.80 \\
\hline Garlic (Allium sativum) & 0.50 & 0.50 & 0.43 & 0.45 & 0.48 & 0.53 & 0.55 & 0.58 \\
\hline African nutmeg (Monodora myristica) & 1.00 & 1.00 & 0.85 & 0.90 & 0.95 & 1.05 & 1.10 & 1.15 \\
\hline Groundnut paste (Arachis hypogea) & 31.50 & 31.50 & 26.78 & 28.35 & 29.93 & 33.08 & 34.65 & 36.23 \\
\hline Magi seasoning & 1.50 & 1.50 & 1.28 & 1.35 & 1.43 & 1.56 & 1.65 & 1.73 \\
\hline Salt & 3.00 & 3.00 & 2.55 & 2.70 & 2.85 & 3.15 & 3.30 & 3.45 \\
\hline Sugar & 3.00 & 3.00 & 2.55 & 2.70 & 2.85 & 3.15 & 3.30 & 3.45 \\
\hline Water & 36.00 & 36.00 & 30.60 & 32.40 & 34.20 & 37.80 & 39.60 & 41.40 \\
\hline \multicolumn{9}{|l|}{$\begin{array}{l}\text { TK - Traditional kilishi (100\% ingredients) } \\
\text { SK1 - Sausage-type kilishi (100\% ingredients) } \\
\text { SK2 - Sausage-type kilishi ( } 85 \% \text { Ingredients) } \\
\text { SK3 - Sausage-type kilishi ( } 90 \% \text { ingredients) } \\
\text { SK4 - Sausage-type kilishi (95\% ingredients) } \\
\text { SK5 - Sausage-type kilishi (105\% ingredients) } \\
\text { SK6 - Sausage-type kilishi (110\% ingredients) } \\
\text { SK7 - Sausage-type kilishi (115\% ingredients) }\end{array}$} \\
\hline
\end{tabular}

Table 1: Composition of infusion mixtures used in kilishi preparation $(\mathrm{kg} / 100 \mathrm{~kg})$.

and spread out on flat steel trays on a raised platform till sun dried to generate the traditional kilishi. For the sausage-type kilishi, the meat was comminuted with various percentages of the infusing ingredients, spread into thin sheets of approximately $2 \mathrm{~mm}$ thickness on steel trays, cut into long strips and dried. After drying, the traditional kilishi (TK) and respective sausage-type kilishi (SK) were roasted in an oven at a temperature of $100^{\circ} \mathrm{C}$ for $10-15 \mathrm{~min}$. Finally, the finished products were cooled at room temperature, packed and heat sealed in high density polyethylene (HDPE) bags and stored at ambient temperature $(28 \pm$ $2^{\circ} \mathrm{C}$ ) for further analysis.

\section{Storage stability and sampling}

The traditional kilishi and sausage-type kilishi were stored for 150 days at ambient temperature and samples were drawn at specified days and subjected to proximate, chemical and organoleptic analysis.

\section{Chemical analysis}

The samples used for the analysis were assayed in duplicate. The moisture, protein, fat and ash contents of the kilishi samples were determined using the standard methods of AOAC [15] and Nielsen [16]. Peroxide value (PV), free fatty acid (FFA), and thiobarbituric acid (TBA) were determined according to the method described by Nielsen [16].

\section{Organoleptic analysis}

Organoleptic attributes of flavour, juiciness, tenderness, pungency and overall acceptability of the kilishi samples were evaluated by a 30-member in-house consumer panelist selected from among students and staff of Department of Food Science and Technology of the University. A 9-point hedonic scale was used with 9 for like extremely down to 1 for dislike extremely [17].

\section{Statistical analysis}

All the analysis was carried out in triplicates and data obtained were analyzed using analysis of variance (ANOVA) method. Where the variance ratio (F-values) proved significant, Fishers least significant difference (LSD) was used to separate the means.

\section{Results and Discussion}

\section{Proximate composition}

The proximate composition of the kilishi samples are presented in Table 2. There were significant differences $(\mathrm{P} \leq 0.05)$ in all the proximate parameters evaluated. The moisture content of the kilishi samples ranged from $10.02 \%-12.02 \%$ with SK 6 having the highest moisture content of $12.02 \%$ and SK2 the lowest moisture content of $10.02 \%$. The reduction in moisture content of SK2 is desirable as this can affect the quality of the sample positively in relation to other kilishi sample [12]. Generally, the moisture content of the kilishi samples indicates that the kilishi samples were sufficiently dried to minimize microbial growth though moisture values of $6.92 \%, 9.87 \%$ and $10.00 \%$ were recorded by Jones et al. [18], Apata et al. [12] and Olusola et al. [19] respectively. The protein content of the entire kilishi samples ranged from $51.62 \%$ in SK2 to 55.84\% in SK7. The range of values obtained with regards to the crude protein content was similar to the values (53.41\%-64.53\%) reported by Isah and Okubanjo [14]. However, significant difference $(\mathrm{P} \leq 0.05)$ occurred in the protein content of the kilishi samples. SK7 had the highest protein content (55.84\%) and SK2 the lowest protein content $(51.62 \%)$. The high crude protein content obtained can be attributed to the various ingredients utilized in the kilishi preparation and is in agreement with report by Igene et al. [9]. The fat content of the kilishi samples differed significantly $(\mathrm{P} \leq 0.05)$ and ranged from $17.34 \%$ in TK to $19.20 \%$ in SK2. Generally, the fat content of the kilishi samples were high and this can be attributed to the groundnut cake powder which represent a considerable proportion of the product [13]. The ash content is an indicator of the mineral content of the meat. The ash content of the kilishi samples ranged from $4.54 \%$ in SK2 to $5.58 \%$ in SK7. The pattern of ash content observed in this study revealed that the higher the slurry infused into the meat during kilishi preparation, the higher the level of ash content in the product. This indicated that most of the ingredients in the slurry might have lost their mineral contents into the slurry hence, into the meat and product and this agrees with the report of Elizabeth [20] who observed that the ash content of any processed meat would be the content of the muscle tissue in addition to that of ingredients used. 


\begin{tabular}{|c|c|c|c|c|}
\hline \multirow{2}{*}{ Kilishi samples } & \multicolumn{4}{|c|}{ Proximate Composition (\%) } \\
\hline & Protein & Fat & Ash & Moisture \\
\hline TK & $54.10 \pm 0.08^{d}$ & $18.38 \pm 0.28^{\mathrm{cd}}$ & $4.82 \pm 0.01^{b}$ & $11.30 \pm 0.01^{\mathrm{ab}}$ \\
\hline SK1 & $53.70 \pm 0.01^{f}$ & $18.57 \pm 0.18^{\mathrm{bc}}$ & $5.01 \pm 0.01^{b c}$ & $11.78 \pm 0.28^{\mathrm{ab}}$ \\
\hline SK2 & $51.62 \pm 0.14^{h}$ & $19.20 \pm 0.23^{a}$ & $4.54 \pm 0.05^{c}$ & $10.02 \pm 0.14^{c}$ \\
\hline SK3 & $52.30 \pm 0.28^{g}$ & $19.03 \pm 0.42^{\mathrm{a}}$ & $4.68 \pm 0.01^{b c}$ & $12.01 \pm 0.18^{a}$ \\
\hline SK4 & $52.84 \pm 0.24^{e}$ & $18.02 \pm 0.11^{d}$ & $4.73 \pm 0.11^{\mathrm{bc}}$ & $11.66 \pm 0.01^{\mathrm{ab}}$ \\
\hline SK5 & $54.78 \pm 0.08^{c}$ & $18.94 \pm 0.16^{\mathrm{ab}}$ & $5.22 \pm 0.23^{\mathrm{ab}}$ & $11.00 \pm 0.01^{b}$ \\
\hline SK6 & $55.20 \pm 0.14^{b}$ & $17.83 \pm 0.44^{d}$ & $5.41 \pm 0.16^{\text {ac }}$ & $12.02 \pm 0.11^{\mathrm{a}}$ \\
\hline SK7 & $55.84 \pm 0.05^{\mathrm{a}}$ & $17.34 \pm 0.09^{e}$ & $5.58 \pm 0.08^{a}$ & $11.26 \pm 0.04^{\mathrm{ab}}$ \\
\hline $\begin{array}{l}\text { a-hMeans with diffe } \\
\text { TK - Traditional ki } \\
\text { SK1 - Sausage-ty } \\
\text { SK2 - Sausage-ty } \\
\text { SK3 - Sausage-ty } \\
\text { SK4 - Sausage-ty } \\
\text { SK5 - Sausage-ty } \\
\text { SK6 - Sausage-ty } \\
\text { SK7 - Sausage-ty }\end{array}$ & $\begin{array}{l}\text { column differ s } \\
\text { ts) } \\
\text { s) } \\
\text { ) } \\
\text { s) } \\
\text { ts) } \\
\text { ts) } \\
\text { ts) }\end{array}$ & .05 & & \\
\hline
\end{tabular}

Table 2: Mean values of proximate composition of kilishi samples.

\section{Free fatty acid (FFA)}

The FFA content in a product is an indication of the quality of the product. Lipid hydrolysis development strongly depends on the hydrolytic enzyme content and it is also influenced by different external and internal factors. The FFA content of the kilishi samples are presented in Figure 1. The FFA values ranged from 3.12\%-11.18\% oleic acid and the FFA content significantly increased $(\mathrm{P} \leq 0.05)$ in all the samples during the 150 days of storage. However, SK2 showed higher FFA values and it is significantly different $(\mathrm{P} \leq 0.05)$ when compared with the other kilishi samples. Also, it was observed that the FFA content of the kilishi samples decreased progressively as the percentage of ingredients used in processing the kilishi increases. SK7 had the lowest FFA content and SK2 the highest FFA content in all the storage days. This result obtained suggests that the various ingredients (concentration) used in processing of the kilishi samples especially the spices inhibited FFA production and is in agreement with the findings of Ogbonnaya and Imidobah [6] and Mgbemere et al. [21].

\section{Peroxide value}

The changes of peroxide value as primary products of lipid oxidation of the kilishi samples are shown in Figure 2. The PV content significantly increased $(\mathrm{P} \leq 0.05)$ in all the kilishi samples during the 150 days storage and there were significant differences $(\mathrm{P} \leq 0.05)$ among the samples. The highest value $(35 / 11 \mathrm{mEq} / \mathrm{kg})$ of peroxide was recorded for SK2 while the lowest value $(8.24 \mathrm{mEq} / \mathrm{kg})$ was observed in SK7. Also, it was observed that the PV content decreased progressively as the percentage of ingredients inclusion used in processing the kilishi samples increases. Since peroxides are inversely related to development if rancidity, it is inferential that the sample with the highest inclusion of ingredients, SK7 (115\% ingredients) was the most effective in slowing down primary oxidation when compared to the other kilishi samples. This result is in agreement with report by Mgbemere et al. [21]. It also agrees with the studies of Siripongvutikorn et al. [22] that spices activities as antioxidant are directly related to their concentration.

\section{Thiobarbituric acid (TBA)}

TBA is a widely used indicator for the assessment of degree of secondary lipid oxidation. It evaluates the second stage of autoxidation during which the peroxides are oxidized to aldehyde and ketones which impart the disagreeable rancid odours and flavour. The effect of storage duration on TBA value of the kilishi samples stored at ambient temperature $\left(28 \pm 2^{\circ} \mathrm{C}\right)$ is shown in Figure 3. The TBA values increased in all the samples over time particularly in SK2. The initial TBA values ranged from $0.26 \mathrm{mgMDA} / \mathrm{kg}$ in SK7 to $0.33 \mathrm{mgMDA} / \mathrm{kg}$ in SK2. After 150 days of storage at $28 \pm 2{ }^{\circ} \mathrm{C}$, the TBA values ranged from $0.97 \mathrm{mgMDA} / \mathrm{kg}$ inSK7 to $1.57 \mathrm{mgMDA} / \mathrm{kg}$ in SK2, thus indicating that TBA of SK7 increased by $0.71 \mathrm{mgMDA} / \mathrm{kg}$, while the TBA of SK2 increased by $1.24 \mathrm{mgMDA} / \mathrm{kg}$ after 150 days. This result indicates that high concentration of spices is effective in retarding lipid oxidation and is in agreement with reports by Siripongvutikorn et al. [22]. However, the results obtained are within the acceptable limits of the maximum level of TBA value, indicating good quality of the kilishi samples during storage, which is $1-2 \mathrm{mgMDA} / \mathrm{kg}$ lipid.

\section{Organoleptic analysis}

The organoleptic evaluation of food products to any food processing technology is very important in determining the consumer acceptability. The results of sensorial analysis for the kilishi samples stored at ambient temperature for 150 days are presented in Tables 3-6. The results obtained shows that there were significant variations $(\mathrm{P} \leq 0.05)$ in all the sensory parameters evaluated. With regards to flavour, the highest flavor of $8.43 \pm 0.56$ for day one, $7.60 \pm 0.36$ for day $50,6.30 \pm 0.47$ for day 100 and $5.55 \pm 0.31$ were observed in SK2. Physiologically, the perception of flavour involves the detection of four basic sensations including saltiness, sweetness, sourness and bitterness by the nerve endings of the surface of the tongue [23]. This result reveals that the flavour of SK2 was higher probably because the fat content of the product was relatively high and the moisture content was also low hence the high flavour of the product compared to the other kilishi samples and this is in conformity with the findings of Olusola et al. [19] and Apata et al. [12]. It also supports the observation of Melton [24] that as the fat of meat increases so does the flavour.

In relation to pungency, there were significant variations $(\mathrm{P} \leq$ 0.05) among the kilishi samples. According to Olusola et al. [19], the hotness of kilishi is an evaluation of the pungency of the product. The results of pungency as shown in Tables 3-6 reveals that SK7 had the highest pungent scores compared to the other kilishi samples in all the respective days of storage evaluated. This suggests that as the percentage of the spices used in the infusing mixtures increases, the pungent level also increases. This agrees with the report of Isah and Okubanjo [14]. 


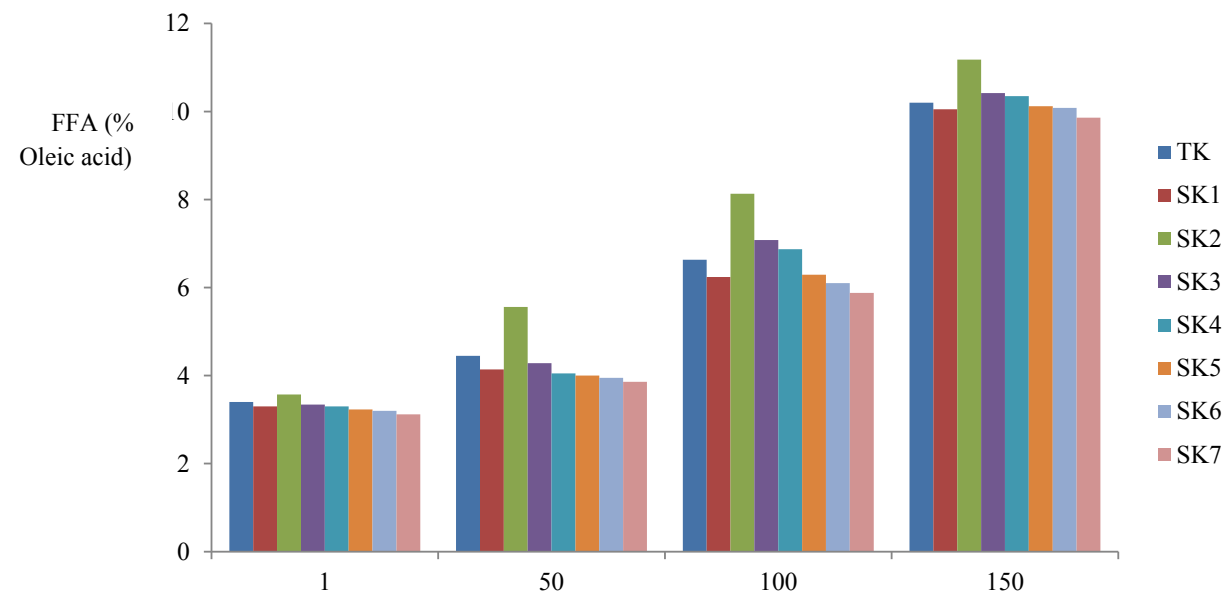

Storage duration (days)

TK - Traditional kilishi (100\% ingredients)

SK1 - Sausage-type kilishi (100\% ingredients)

SK2 - Sausage-type kilishi (85\% Ingredients)

SK3 - Sausage-type kilishi (90\% ingredients)

SK4 - Sausage-type kilishi (95\% ingredients)

SK5 - Sausage-type kilishi (105\% ingredients)

SK6 - Sausage-type kilishi ( $110 \%$ ingredients)

SK7 - Sausage-type kilishi (115\% ingredients)

Figure 1: Effect of storage duration on free fatty acid (FFA) of kilishi samples.

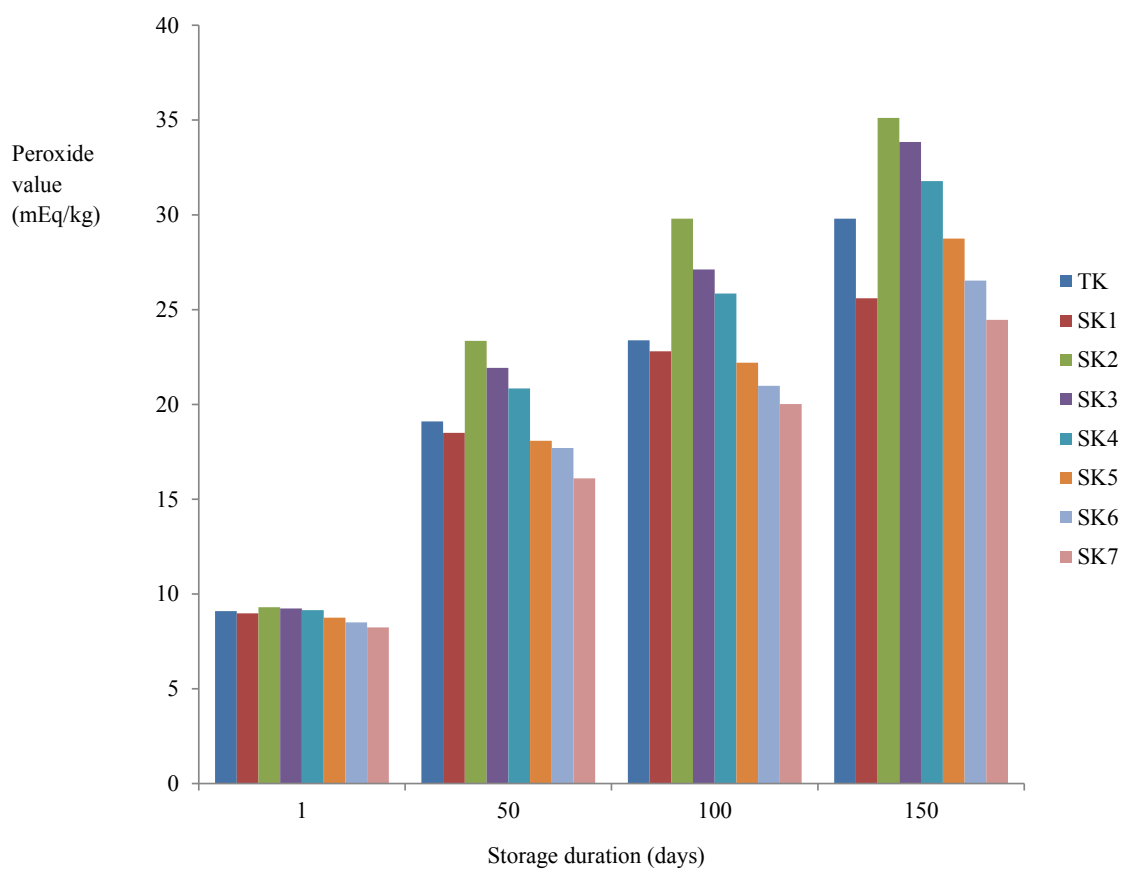

TK - Traditional kilishi (100\% ingredients)

SK1 - Sausage-type kilishi (100\% ingredients)

SK2 - Sausage-type kilishi (85\% Ingredients)

SK3 - Sausage-type kilishi (90\% ingredients)

SK4 - Sausage-type kilishi (95\% ingredients)

SK5 - Sausage-type kilishi (105\% ingredients)

SK6 - Sausage-type kilishi (110\% ingredients)

SK7 - Sausage-type kilishi (115\% ingredients)

Figure 2: Effect of storage duration on peroxide value $(\mathrm{mEq} / \mathrm{kg})$ of kilishi samples. 
Citation: Iheagwara MC, Okonkwo TM (2016) Influence of Storage Duration on Stability and Sensorial Quality of Dried Beef Product (Kilishi). J Food Process Technol 7: 574. doi:10.4172/2157-7110.1000574

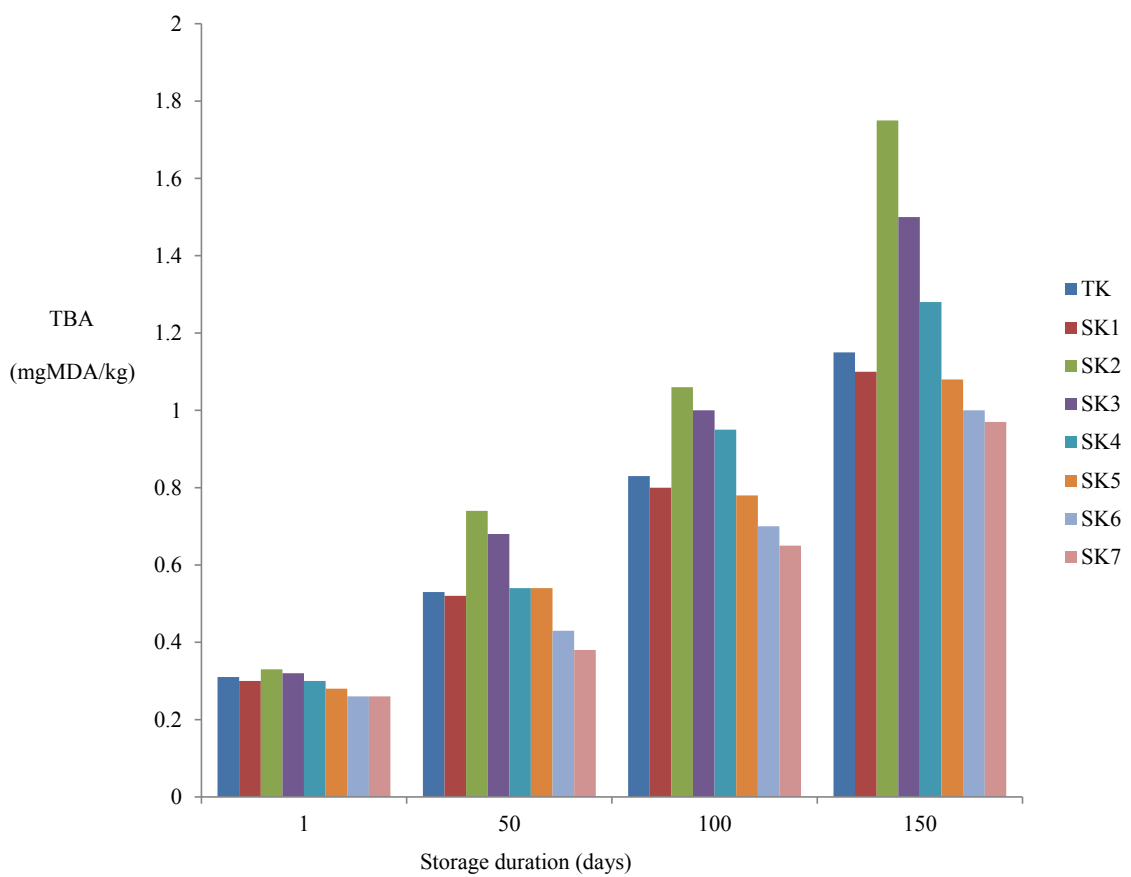

STK - Traditional kilishi (100\% ingredients)

SK1 - Sausage-type kilishi (100\% ingredients)

SK2 - Sausage-type kilishi (85\% Ingredients)

SK3 - Sausage-type kilishi (90\% ingredients)

SK4 - Sausage-type kilishi (95\% ingredients)

SK5 - Sausage-type kilishi (105\% ingredients)

SK6 - Sausage-type kilishi (110\% ingredients)

SK7 - Sausage-type kilishi (115\% ingredients)

Figure 3: Effect of storage duration on thiobarbituric acid (TBA) value of kilishi samples.

\begin{tabular}{|c|c|c|c|c|c|}
\hline \multirow{2}{*}{ Kilishi samples } & \multicolumn{5}{|c|}{ Sensory Parameter } \\
\hline & Flavour & Pungency & Juiciness & Tenderness & Overall acceptability \\
\hline TK & $7.86 \pm 0.52^{f}$ & $7.18 \pm 0.34^{\mathrm{e}}$ & $7.18 \pm 0.45^{b}$ & $7.15 \pm 0.51^{f}$ & $7.63 \pm 0.28^{f}$ \\
\hline SK1 & $8.06 \pm 0.32^{d}$ & $7.65 \pm 0.42^{\mathrm{d}}$ & $7.13 \pm 0.23^{c}$ & $7.25 \pm 0.37^{e}$ & $7.75 \pm 0.44^{d}$ \\
\hline SK2 & $8.43 \pm 0.56^{a}$ & $7.64 \pm 0.53^{\mathrm{d}}$ & $7.15 \pm 0.33^{\mathrm{bc}}$ & $7.53 \pm 0.49^{b}$ & $8.00 \pm 0.78^{a}$ \\
\hline SK3 & $8.15 \pm 0.46^{b}$ & $7.78 \pm 0^{\prime} 41^{c}$ & $7.23 \pm 0.48^{a}$ & $7.62 \pm 0.38^{a}$ & $7.93 \pm 0.37^{b}$ \\
\hline SK4 & $8.10 \pm 0.49^{c}$ & $7.84 \pm 0.42^{\mathrm{b}}$ & $7.12 \pm 0.43^{c}$ & $7.41 \pm 0.52^{c}$ & $7.88 \pm 0.45^{c}$ \\
\hline SK5 & $8.05 \pm 0.34^{d}$ & $7.85 \pm 0.32^{\mathrm{b}}$ & $7.08 \pm 0.23^{d}$ & $7.26 \pm 0.37^{e}$ & $7.68 \pm 0.49^{e}$ \\
\hline SK6 & $8.00 \pm 0.33^{e}$ & $7.98 \pm 0.41^{\mathrm{a}}$ & $7.00 \pm 0.28^{\mathrm{e}}$ & $7.33 \pm 0.32^{d}$ & $7.50 \pm 0.18^{g}$ \\
\hline SK7 & $7.82 \pm 0.48^{f}$ & $8.00 \pm 0.52^{\mathrm{a}}$ & $6.58 \pm 0.49^{f}$ & $7.04 \pm 0.45^{\mathrm{g}}$ & $7.08 \pm 0.33^{h}$ \\
\hline $\begin{array}{l}\text { a-hMeans with diffe } \\
\text { TK - Traditional ki } \\
\text { SK1 - Sausage-ty } \\
\text { SK2 - Sausage-ty } \\
\text { SK3 - Sausage-ty } \\
\text { SK4 - Sausage-ty } \\
\text { SK5 - Sausage-ty } \\
\text { SK6 - Sausage-ty } \\
\text { SK7 - Sausage-ty }\end{array}$ & $\begin{array}{l}\text { ng the column } \\
\text { nts) } \\
\text { redients) } \\
\text { edients) } \\
\text { edients) } \\
\text { edients) } \\
\text { redients) } \\
\text { edients) } \\
\text { redients) }\end{array}$ & ntly at $P \leq 0.05$ & & & \\
\hline
\end{tabular}

Table 3: Mean sensory scores of Kilishi samples stored for one day.

According to Moloney [25], meat juiciness is an important component of meat tenderness and palatability and it has two major components; the first is the impression of wetness produced by the release of fluid from the meat during the first few chews, while the second is the more sustained juiciness that apparently results from the stimulating effect of fat on the production of saliva and coating of fat that builds up in the tongue, teeth and other parts of the mouth. The results of juiciness of the kilishi samples were significantly different (P $\leq 0.05)$. For day one, SK3 had the highest $(7.23 \pm 0.48)$ juiciness score while for day 50 , SK4 was juicier $(6.81 \pm 0.22)$ than the other kilishi samples. For day 100 and 150 respectively, SK2 had the highest juiciness scores of $5.64 \pm 0.28$ and $5.02 \pm 0.43$ respectively compared to the other 
Citation: Iheagwara MC, Okonkwo TM (2016) Influence of Storage Duration on Stability and Sensorial Quality of Dried Beef Product (Kilishi). J Food Process Technol 7: 574. doi:10.4172/2157-7110.1000574

Page 6 of 7

\begin{tabular}{|c|c|c|c|c|c|}
\hline \multirow{2}{*}{ Kilishi samples } & \multicolumn{5}{|c|}{ Sensory parameter } \\
\hline & Flavour & Pungency & Juiciness & Tenderness & Overall acceptability \\
\hline TK & $7.30 \pm 0.44^{d}$ & $6.84 \pm 0.23^{h}$ & $6.41 \pm 0.32^{\mathrm{e}}$ & $6.62 \pm 0.48^{e}$ & $6.71 \pm 0.33^{c}$ \\
\hline SK1 & $7.53 \pm 0.33^{b}$ & $7.20 \pm 0.52^{\mathrm{d}}$ & $6.52 \pm 0.21^{\mathrm{cd}}$ & $6.65 \pm 0.36^{\mathrm{de}}$ & $6.80 \pm 0.44^{b}$ \\
\hline SK2 & $7.60 \pm 0.36^{a}$ & $6.92 \pm 0.33 g$ & $6.68 \pm 0.42^{b}$ & $6.76 \pm 0.42 c$ & $7.10 \pm 0.38^{a}$ \\
\hline SK3 & $7.42 \pm 0.18^{c}$ & $7.04 \pm 0.41^{f}$ & $6.76 \pm 0.33^{a}$ & $6.84 \pm 0.33^{b}$ & $6.84 \pm 0.49^{b}$ \\
\hline SK4 & $7.40 \pm 0.24^{c}$ & $7.12 \pm 0.28^{e}$ & $6.81 \pm 0.22^{\mathrm{a}}$ & $6.93 \pm 0.47^{a}$ & $6.53 \pm 0.21^{d}$ \\
\hline SK5 & $7.38 \pm 0.48^{c}$ & $7.43 \pm 0.33^{c}$ & $6.54 \pm 0.38^{c}$ & $6.68 \pm 0.32^{d}$ & $6.41 \pm 0.32^{\mathrm{e}}$ \\
\hline SK6 & $7.27 \pm 0.51^{\mathrm{de}}$ & $7.51 \pm 0.42^{\mathrm{b}}$ & $6.48 \pm 0.41^{d}$ & $6.34 \pm 0.24^{f}$ & $6.23 \pm 0.24^{f}$ \\
\hline SK7 & $7.24 \pm 0.38^{e}$ & $7.74 \pm 0.38^{a}$ & $6.25 \pm 0.35^{f}$ & $6.20 \pm 0.43^{9}$ & $6.08 \pm 0.32^{\mathrm{g}}$ \\
\hline $\begin{array}{l}\text { a-hMeans with diff } \\
\text { TK - Traditional } k \\
\text { SK1 - Sausage-ty } \\
\text { SK2 - Sausage-ty } \\
\text { SK3 - Sausage-ty } \\
\text { SK4 - Sausage-ty } \\
\text { SK5 - Sausage-ty } \\
\text { SK6 - Sausage-ty } \\
\text { SK7 - Sausage-ty }\end{array}$ & $\begin{array}{l}\text { the column di } \\
\text { s) } \\
\text { dients) } \\
\text { ients) } \\
\text { ients) } \\
\text { ients) } \\
\text { dients) } \\
\text { dients) } \\
\text { dients) }\end{array}$ & $y$ at $P \leq 0.05$. & & & \\
\hline
\end{tabular}

Table 4: Mean sensory scores of kilishi samples stored for 50 days.

\begin{tabular}{|c|c|c|c|c|c|}
\hline \multirow{2}{*}{ Kilishi samples } & \multicolumn{5}{|c|}{ Sensory parameter } \\
\hline & Flavour & Pungency & Juiciness & Tenderness & Overall acceptability \\
\hline TK & $6.11 \pm 0.36^{c}$ & $6.30 \pm 0.48^{c}$ & $5.18 \pm 0.23^{c}$ & $5.48 \pm 0.32^{\mathrm{cd}}$ & $5.59 \pm 0.21^{c}$ \\
\hline SK1 & $6.18 \pm 0.19^{b}$ & $6.27 \pm 0.35^{d}$ & $5.20 \pm 0.11^{c}$ & $5.52 \pm 0.22^{c}$ & $5.68 \pm 0.45^{b}$ \\
\hline SK2 & $6.30 \pm 0.47^{a}$ & $6.18 \pm 0.47 f$ & $5.64 \pm 0.28^{a}$ & $5.80 \pm 0.43^{a}$ & $5.88 \pm 0.21^{b}$ \\
\hline SK3 & $6.22 \pm 0.51^{b}$ & $6.20 \pm 0.35^{\text {ef }}$ & $5.43 \pm 0.41^{b}$ & $5.63 \pm 0.35^{b}$ & $5.70 \pm 0.41^{a}$ \\
\hline SK4 & $6.20 \pm 0.22^{b}$ & $6.23 \pm 0.21^{\mathrm{e}}$ & $5.22 \pm 0.32^{c}$ & $5.51 \pm 0.28^{c}$ & $5.62 \pm 0.28^{c}$ \\
\hline SK5 & $6.18 \pm 0.18^{b}$ & $6.29 \pm 0.31^{d}$ & $5.11 \pm 0.27^{d}$ & $5.45 \pm 0.34^{\mathrm{de}}$ & $5.53 \pm 0.38^{d}$ \\
\hline SK6 & $6.07 \pm 0.34^{c}$ & $6.35 \pm 0.48^{b}$ & $5.08 \pm 0.12^{\mathrm{d}}$ & $5.40 \pm 0.18^{e}$ & $5.50 \pm 0.42^{d}$ \\
\hline SK7 & $5.96 \pm 0.47^{d}$ & $6.41 \pm 0.32^{\mathrm{a}}$ & $5.01 \pm 0.11^{\mathrm{e}}$ & $5.32 \pm 0.21^{f}$ & $5.48 \pm 0.22^{\mathrm{d}}$ \\
\hline $\begin{array}{l}\text { a-hMeans with diffe } \\
\text { TK - Traditional ki } \\
\text { SK1 - Sausage-ty } \\
\text { SK2 - Sausage-ty } \\
\text { SK3 - Sausage-ty } \\
\text { SK4 - Sausage-ty } \\
\text { SK5 - Sausage-ty } \\
\text { SK6 - Sausage-ty } \\
\text { SK7 - Sausage-ty }\end{array}$ & $\begin{array}{l}\text { the column d } \\
\text { s) } \\
\text { dients) } \\
\text { ients) } \\
\text { ients) } \\
\text { ients) } \\
\text { dients) } \\
\text { dients) } \\
\text { dients) }\end{array}$ & ly at $P \leq 0.05$ & & & \\
\hline
\end{tabular}

Table 5: Mean sensory scores of kilishi samples stored for 100 days.

\begin{tabular}{|c|c|c|c|c|c|}
\hline \multirow{2}{*}{ Kilishi samples } & \multicolumn{5}{|c|}{ Sensory parameter } \\
\hline & Flavour & Pungency & Juiciness & Tenderness & Overall acceptability \\
\hline TK & $5.32 \pm 0.43^{c d}$ & $5.43 \pm 0.32^{b}$ & $4.84 \pm 0.21^{c}$ & $4.70 \pm 0.32^{\circ}$ & $4.48 \pm 0.24^{\mathrm{d}}$ \\
\hline SK1 & $5.40 \pm 0.22^{b}$ & $5.30 \pm 0.25^{c}$ & $4.91 \pm 0.33^{b}$ & $4.78 \pm 0.26^{b}$ & $4.56 \pm 0.33^{c}$ \\
\hline SK2 & $5.55 \pm 0.31^{a}$ & $5.20 \pm 0.22^{\mathrm{e}}$ & $5.02 \pm 0.43^{a}$ & $4.98 \pm 0.41^{a}$ & $4.80 \pm 0.22^{\mathrm{a}}$ \\
\hline SK3 & $5.35 \pm 0.43^{c}$ & $5.24 \pm 0.31^{\mathrm{de}}$ & $4.94 \pm 0.45^{b}$ & $4.92 \pm 0.34^{\mathrm{a}}$ & $4.68 \pm 0.23^{b}$ \\
\hline SK4 & $5.30 \pm 0.21^{d}$ & $5.29 \pm 0.42^{\text {cd }}$ & $4.80 \pm 0.31^{c}$ & $4.62 \pm 0.25^{d}$ & $4.61 \pm 0.35^{c}$ \\
\hline SK5 & $5.24 \pm 0.22^{\mathrm{e}}$ & $5.32 \pm 0.26^{c}$ & $4.68 \pm 0.42^{d}$ & $4.50 \pm 0.18^{e}$ & $4.50 \pm 0.22^{d}$ \\
\hline SK6 & $5.20 \pm 0.36^{e}$ & $5.48 \pm 0.33^{a b}$ & $4.60 \pm 0.22^{\mathrm{e}}$ & $4.42 \pm 0.23^{f}$ & $4.41 \pm 0.26^{\mathrm{e}}$ \\
\hline SK7 & $5.08 \pm 0.24^{f}$ & $5.50 \pm 0.24^{a}$ & $4.53 \pm 0.26^{f}$ & $4.28 \pm 0.33^{9}$ & $4.35 \pm 0.24^{f}$ \\
\hline $\begin{array}{l}\text { a-hMeans with diff } \\
\text { TK - Traditional ki } \\
\text { SK1 - Sausage-ty } \\
\text { SK2 - Sausage-ty } \\
\text { SK3 - Sausage-ty } \\
\text { SK4 - Sausage-ty } \\
\text { SK5 - Sausage-ty } \\
\text { SK6 - Sausage-ty } \\
\text { SK7 - Sausage-ty }\end{array}$ & $\begin{array}{l}\text { the column dif } \\
\text { s) } \\
\text { dients) } \\
\text { ients) } \\
\text { ents) } \\
\text { ents) } \\
\text { dients) } \\
\text { dients) } \\
\text { dients) }\end{array}$ & $y$ at $P \leq 0.05$ & & & \\
\hline
\end{tabular}

Table 6: Mean sensory scores of kilishi samples stored for 150 days. 
Citation: Iheagwara MC, Okonkwo TM (2016) Influence of Storage Duration on Stability and Sensorial Quality of Dried Beef Product (Kilishi). J Food Process Technol 7: 574. doi:10.4172/2157-7110.1000574

kilishi samples. However, the juiciness of all the kilishi samples were inversely proportional to the storage duration though the juiciness as detected by the consumer are dependent on the intramuscular lipids and water content of the meat [19].

The tenderness of meat can be defined as the secondary manifestation of the structure of meat and the manner in which this structure reacts to the force applied during biting and the specific senses involved in eating [25]. It is how meat feels in the mouth during manipulation and mastication [19]. The result of tenderness of the kilishi samples as shown in Tables 3-6 shows that there were significant differences $(\mathrm{P} \leq 0.05)$ in the tenderness of the kilishi samples. For day one, SK3 was more tenderly $(7.62 \pm 0.38)$ than the other kilishi samples. For day 50, SK4 had the highest tenderness score of $6.93 \pm$ 0.47 compared to others. For days 100 and 150, SK2 had the highest tenderness of $5.80 \pm 0.35$ and $4.98 \pm 0.34$ respectively compared to the other kilishi samples. This variation in tenderness of the kilishi samples can be attributed to a large extent on the variations in the ingredients used since the same semitendinosus muscle and processing method were adopted throughout the experiment especially for the sausagetype kilishi samples. Also, this result confirms the report of Moloney [25] who said that meat juiciness is an important component of meat tenderness and palatability. Similarly, the tenderness of the kilishi samples was inversely proportional to the storage duration.

The mean panel ratings for the overall acceptability of the kilishi sample as shown in Tables 3-6 reveals that there were significant ( $\mathrm{P}$ $\leq 0.05$ ) differences among the kilishi samples. The result obtained in relation to the overall acceptability indicates that the panelist preferred SK2 greatly compared to other kilishi samples in all the storage days. Among the kilishi samples, SK7 had the least rating in overall acceptability. This result obtained indicates that the level of inclusion of the spices used in the kilishi production affected the consumer preference as the panelist preferred SK2 (8.5\% ingredients) to the hot pungent SK7 (115\% ingredient). This result is in agreement with the findings of Isah and Okubanjo [14].

\section{Conclusion}

The present study has demonstrated that inclusion of infusion ingredients to a level of $115 \%$ possesses anti-oxidative property that retards oxidative rancidity thus extending the shelf stability of the kilishi. This is justified by the low peroxide, free fatty acid and thiobarbituric acid levels of kilishi sample processed using 115\% ingredient inclusion compared to other percentage ingredients inclusion.

\section{References}

1. Forrest JC, Aberle ED, Gerrard DE, Mills WE, Hedrick HB, et al. (2001) The principles of meat science. (4thedn), Kendall/Hunt Publishing company, USA.

2. Ikeme Al (1990) Meat science and technology-A comprehensive approach. Africana FEP Publishers Ltd., Onitsha, Nigeria.

3. Miller RK (2002) Factors affecting the quality of raw meat processing: Improving quality. In: Kerry J, Lediord D (eds.) CRC Press LLC., USA.

4. Fonkem DN, Tanya VN, Ebangi AL (2010) Effect of season on the microbiological quality of Kilishi, a traditional Cameroonian dried beef product. Tropicultura. 28 (1): 10-15.

5. FAO (2007) Manual on meat cold store operations and management, Agriculture and consumer protection. FAO Corporate Document Repository, FAO Rome.

6. Ogbonnaya C, Imodiboh LI (2009) Influence of storage conditions on shelf-life of dried beef product (Kilishi). World Journal of Agricultural sciences, 5: 34-39.

7. Lawrie RA (1989). Meat science, Pergamon Press, London.

8. Igene JO (1988). Lipid, fatty acid composition and storage stability of Kilishi - a sundried meat product. Tropical Science. 28:153-161.

9. Igene JO, Abubakar U, Akanbi CT, Negbenebor CA (1993). Effect of sodium tripolyphosphate and moisture level on the drying characteristics and yield of Kilishi. Journal of Agriculture, Science and Technology. 3(2): 166-173.

10. Ogunsola OD, Omojola AB (2008) Qualitative evaluation of kilishi prepared from beef and pork. African Journal of Biotechnology. 7: 1753-1758.

11. Musonge P, Njolai EN (1994) Drying and infusion during the traditional processing of kilishi. Journal of Food Engineering 23: 159-168.

12. Apata ES, Osidibo OO, Apata OC, Okubanjo AO (2013). Effects of different solar drying methods on quality attributes of dried meat production (kilishi). Journal of Food Research 2: 80-86

13. Igene JO, Farouk MM, Akanbi CT (1990) Preliminary studies on the traditional processing of Kilishi. Journal of Science, Food and Agriculture. 50: 89-98.

14. Isah OA, Okunbanjo AO (2012). Effect of various additives on proximate composition and acceptability of Kilishi made from semitendinosus muscle of white Fulani cattle. Pacific Journal of Science and Technology, 13 (1): 506-511.

15. AOAC (2007). Official methods of analysis (20thedn), Association of Analytical Chemist International, Gathersburg, MD, USA.

16. Nielsen SS (2003). Food analysis (3rdedn) Kluwer Academic/Plemem publishers New York, USA.

17. Carbonell I, Izquierdo L, Costell E (2002). Sensory profiling of cooked gilthead sea bream (Sparus aurata): Sensory evaluation procedures and panel training. Food Science and Technology International. 8(3): 169-177

18. Jones MJ, Tanya VN, Mbofung CMF, Fonkem DN, Silverside DE (2001) A microbiological and nutritional evaluation of the West African dried meat product, Kilishi Journal of Food Technology in Africa. 6:126-129.

19. Olusola OO, Okubanjo AO, Omojola AB (2012) Nutritive and organoleptic characteristics of Kilishi as affected by meat type and ingredients formulation. Journal of Animal Production Advances. 2(5): 221-232.

20. Elizabeth B (1995). Ingredients in processed meat products paper presentation. Department of Animal Science and Industry Kansas state University, USA

21. Mgbemere VN, Akpapunam MA, Igene JO (2011). Effect of groundnut flour substitution on yield, quality and storage stability of Kilishi - a Nigerian indigenous dried meat product. African Journal of Food, Agriculture, Nutrition and Development 11 (2): 4718-4738.

22. Siripongvutikorn S, Patawatchai C, Usawakesmanee W (2009). Effect of herb and spice pastes on the quality changes in minced salmon flesh waste during chilled storage. Asian Journal of Food and Agro - Industry. 2: 481-492.

23. Hedrick HB, Aberle ED, Forrest JC, Judge MD, Merkel RA (1994) Principles of Meat Science, (3rdedn) Kendall Hunt Publishing Co. Dubuque, lowa.

24. Melton SL (1990) Effects of feed on flavor of red meat: a review. J Anim Sci 68: 4421-4435.

25. Moloney A (1999) The quality of meat from beef cattle - is it influenced by diet? In R \& Hall, Technical Bulletin issue No.4. 